\title{
Kajian Pengaruh Penggunaan Model Pembelajaran Picture And Picture Terhadap Prestasi Belajar IPA Siswa Sekolah Dasar
}

\author{
Leni Marlina \\ Dosen Program Studi Pendidikan Bahasa dan Sastra Indonesia, STKIP Yapis Dompu \\ Email : sayalenimarlina@gmail.com
}

Article History: Received: 2020-10-09 || Revised: 2020-11-03 || Published: 2020-11-17
Sejarah Artikel : Diterima: 2020-10-09 || Direvisi: 2020-11-03 || Dipublikasi: 2020-11-17

\begin{abstract}
This research is motivated by the problems that accur in elementray school. These problems include the media used only as a blacboard, no intersting activities such as group discussions, too many foreigh terms, too dense materia. In addition, teachers tend to dominate learning, and teacher mastery of the material is weak and too monotonous, students rarely ask questions or express opinions. Therefore the material taught verbally/ memorizing, as well as student learning achievement in science is very low. The propose of this study was to see the effect of using the picture and picture learning achievement of elementary school students. While the type of this ( research is library) study is a study that is used to collect information and data with the help of various forms of material in the library such as documents, books, magazines, articles, historical stories and so on. This research was conducted from April 13 to May 23, 2020. Data collection was carried out by analyzing several articles and journals relevant to the research title. The resurtls showed the influence of the use of the picture and picture learning model on student achievement which can be seen from the differences in student lerning outcomes using the picture and picture learning model with conventional learning models such as lectures without any other learning media. Where by using the picture and picture learning model student learning achievement increases and is more optimal.
\end{abstract}

Key words : Picture and Picture, Learning, Achievement

\begin{abstract}
Abstrak
Penelitian ini dilatarbelakangi oleh permasalahan-permasalahan yang terjadi di sekolah dasar. Permasalahanpermasalahan tersebut antara lain media yang digunakan hanya sebatas papan tulis, tidak ada kegiatan yang menarik seperti diskusi kelompok, terlalu banyak istilah asing, materi yang terlalu padat. Selain itu guru cenderung mendominasi pembelajaran, dan penguasaan guru akan materi lemah dan terlalu monoton, siswa jarang mengajukan pertanyaan atau mengutarakan pendapat. Oleh sebab itu materi yang diajarkan menjadi verbal/hafalan, serta prestasi belajar IPA siswa sangat rendah. Tujuan dari penelitian ini adalah untuk melihat pengaruh dari penggunaan model pembelajaran picture and picture terhadap prestasi belajar siswa sekolah dasar. Sedangkan jenis penelitian ini adalah penelitian studi kepustakaan (library research). Studi kepustakaan merupakan suatu studi yang digunakan dalam mengumpulkan informasi dan data dengan bantuan berbagai macam bentuk material yang ada di perpustakaan seperti dokumen, buku, majalah, artikel, kisah-kisah sejarah dan sebagainya. Penelitian ini dilakukan mulai pada tanggal 13 April sampai dengan tanggal 23 Mei 2020. Pengambilan data dilakukan dengan menganalisis beberapa artikel dan jurnal yang relevan dengan judul penelitian. Hasil penelitian menunjukan adanya pengaruh dari penggunaan model pembelajaran picture and picture terhadap prestasi belajar siswa yang dapat dilihat dari perbedaan hasil belajar siswa yang menggunakan model pembelajaran picture and picture dengan model pembelajaran konvensional seperti ceramah tanpa ada media belajar lain. Dimana dengan menggunakan model pembelajaran picture and picture prestasi belajar siswa meningkat dan lebih optimal.
\end{abstract}

Kata kunci : picture and picture, prestasi, belajar

\section{PENDAHULUAN}

Undang-Undang Nomor 23 Tahun 2003 Tentang Sistem Pendidikan Nasional Pasal 1 ayat (1) menjelaskan bahwa pendidikan adalah usaha sadar dan terencana untuk mewujudkan suasana belajar dan proses pembelajaran agar peserta didik secara aktif mengembangkan potensi dirinya untuk memiliki 
kekuatan spiritual keagamaan, pengendalian diri, kepribadian, kecerdasan, akhlak mulia, serta keterampilan yang diperlukan dirinya, masyarakat bangsa dan negara.

Pendidikan yang bermutu terlahir dari proses pembelajaran yang berkualitas. Upaya mewujudkan mutu pendidikan haruslah dilaksanakan terus menerus dan sepanjang masa. Salah satu faktor terlaksananya proses pembelajaran adalah pembelajaran siswa aktif. Dalam hal ini, peran guru sangat diharapkan bisa menciptakan situasi pendidikan atau pengajaran yang menstimulasi siswa aktif belajar, bukan hanya sekedar menjadi pihak pasif (penerima) belajar saja. Perbaikan metode yang digunakan juga mendorong terciptanya proses pembelajaran yang bermutu dengan siswanya yang aktif. Mata pelajaran Ilmu Pengetahuan Alam (IPA) termasuk mata pelajaran yang cukup sulit dipahami. Hal ini bukan hanya karena kompleks, tetapi juga karena banyak istilah ilmiah yang perlu pencermatan yang mendalam. IPA di sekolah dasar memiliki tujuan agar siswa memiliki keterampilan proses, mempunyai minat mempelajari alam sekitar, bersikap ilmiah, mampu menerapkan konsep-konsep IPA untuk menjelaskan gejala-gejala alam dan memecahkan masalah dalam kehidupan sehari-hari, mencintai alam sekitar, serta menyadari kebesaran dan keagungan tuhan (Fitrih, 2016:1).

Winda Meidhita Gamiarsy (2017:21) dalam penelitiannya yang berjudul Pengaruh Penerapan Model Pembelajaran Kooperatif Tipe Picture And Picture Terhadap Hasil Belajar IPA Siswa Kelas V SDN 1 Sri Pendowo Ketapang Lampung Selatandengan jenis penelitian Eksperimen,menemukan permasalahan yang biasa timbul dalam belajar Ilmu Pengetahuan Alam (IPA) diantaranya adalah proses pembelajaran yang terjadi masih berpusat pada guru dan kurang memberi kesempatan kepada siswa untuk mengalami dan membangun pengetahuannya sendiri. Hal lain yang ditemukan oleh Hidayati (2014:1) dalam penelitiannya menemukan permasalahan yang biasa timbul dalam belajar Ilmu Pengetahuan Alam (IPA) diantaranya adalah proses pembelajaran yang terjadi masih berpusat pada guru, media yang digunakan hanya sebatas papan tulis, tidak ada kegiatan yang menarik seperti diskusi kelompok, siswa jarang mengajukan pertanyaan atau mengutarakan pendapat. Sedangkan Khoir dalam Imanuel Sairo Awang (2015:4) mengemukakan permasalahan yang biasa timbul dalam belajar IPA adalah terlalu banyak istilah asing, materi yang terlalupadat, terbatasnya media pembelajaran, guru cenderung mendominasi pembelajaran, dan penguasaan guru akan materi lemah dan terlalu monoton, serta prestasi belajar IPA siswa sangat rendah

Solusi yang peneliti tawarkan dari permasalahan di atas, yaitu penggunaan model pembelajaran picture and picture. Model pembelajaran Picture and Picture ini dianggap tepat karena merupakan model pembelajaran kooperatif yang menggunakan media gambar sehingga dapat menarik perhatian peserta didik serta dapat membangun ketertarikan bagi peserta didik dalam belajar. Melalui model pembelajaran picture and picture siswa dapat melihat secara langsung gambaran konkret dari materi yang sedang dipelajari melalui media pembelajaran yang digunakan oleh guru. Model pembelajaran picture and picture merupakan suatu model pembelajaran menggunakan gambar dan dipasangkan atau diurutkan menjadi urutan yang logis. Model pembelajaran ini mengandalkan gambar-gambar yang berkaitan dengan materi belajar, peserta didik lebih aktif dan mudah memahami apa yang disampaikan oleh guru sehingga akan memenuhi tujuan pembelajaran yang ingin dicapai. Melalui penerapan model pembelajaran yang sesuai diharapkan dapat mengatasi permasalahan prestasi belajar peserta didik yang masih rendah.

Berangkat dari paparan di atas maka artikel ini akan membahas tentang "Kajian Pengaruh Penggunaan Model Pembelajaran Picture And Picture Terhadap Prestasi Belajar IPA Siswa Sekolah Dasar".

\section{METODE PENELITIAN}

Metode yang digunakan dalam penelitian ini adalah metode studi kepustakaan (library research). Studi kepustakaan merupakan suatu studi yang digunakan dalam mengumpulkan informasi dan data dengan bantuan berbagai macam bentuk material yang ada di perpustakaan seperti dokumen, buku, majalah, kisahkisah sejarah dan sebagainya (Abdi Morzaqon T. \& Dr. Budi Purwoko, 2017). Pendapat lain yang dikemukakan oleh Zed dalam (Supriyadi, 2016) bahwa studi kepustakaan dapat diartikan serangkaian kegiatan yang berkenaan dengan metode pengumpulan data pustaka, membaca dan mencatat serta mengolah bahan penelitian. Lebih lanjut Zed mengemukakan bahwa dalam penelitian studi pustaka setidaknya ada empat ciri utama yang perlu diperhatikan oleh penulis, yaitu:

1) Penulis atau peneliti berhadapan langsung dengan teks (nash) atau data angka, bukan dengan pengetahuan langsung dari lapangan.

2 ) Data pustaka bersifat siap pakai artinya peneliti tidak terjun langsung kelapangan. Karena peneliti berhadapan langsung dengan sumber data yang ada di perpustakaan.

3 ) Data pustaka umumnya adalah sumber sekunder, dalam arti bahwa peneliti memperoleh bahan atau data dari tangan kedua bukan data orisinaldari data pertama di lapangan.

4 ) Kondisi data pustaka tidak dibatasi oleh ruang dan waktu. 
Berdasarkan pendapat di atas dapat disimpulkan bahwa pengumpulan data dalam penelitian kepustakaan dilakukan dengan menelaah beberapa jurnal, buku dan dokumen-dokumen baik yang berbentuk cetak maupun elektronik, serta sumber-sumber data dan informasi lainnya yang dianggap relevan dengan penelitian atau kajian. Adapun waktu dilaksanakan penelitianini yakni mulai pada tanggal 13 April sampai dengan 23 Mei 2020.

\section{HASIL DAN PEMBAHASAN}

\section{A. Hasil}

Hasil dan pembahasan penelitian ini merupakan data yang dikumpulkan dari pengamatan terhadap beberapa artikel tentang pembelajaran Ilmu Pengetahuan Alam (IPA) Sekolah Dasar (SD) dengan menggunakan modelPicture and Picture. Penelitian ini ingin melihat seberapa jauh pengaruh modelPicture and Picture terhadap prestasi belajar Siswa SD. Para ahli pendidikan telah banyak mengemukakan dan mengenalkan metode-metode pembelajaran aktif yang bertujuan untuk mengefektifitaskan proses belajar mengajar. Sarya (dalam Wibawa, 2010:148) berpendapat setiap proses belajar mengajar menuntut upaya penyampaian suatu tujuan tertentu. Arends (dalam Wibawa, 2010:148) juga berpendapat setiap tujuan menuntut pula suatu model bimbingan untuk terciptanya situasi belajar tertentu. Pada proses belajar mengajar, tidak ada suatu metode yang paling baik. Dari hal tersebut, guru perlu menguasai dan dapat menerapkan berbagai metode pembelajaran agar dapat mencapai tujuan pembelajaran yang beranekaragam. Salah satu metode pembelajaran yang cocok diterapkan untuk pembelajaran IPA yaitu metode Picture and Picture.Metode Picture and Picture adalah suatu metode belajar yang menggunakan gambar dan dipasangkan atau diurutkan menjadi urutan yang logis, Kiranawati (dalam Subratayasa, 2012:14).

Berdasarkan hasil penelitian dan analisis data berupa studi kepustakaan (Library research) tentang pengaruh metode pembelajaran picture and picture Terhadap Prestasi Belajar IPA Siswa Sekolah Dasar dapat dilihat pada tulisan Ni Md. Kurniati, Dw. Nym. Sudana dan Ni Nym. Garminah (2012) yang berjudul " Pengaruh Metode Picture And Picture Terhadap Hasil Belajar IPA Siswa Kelas IV SD Semester Genap Di Gugus I Kecamatan Buleleng". Tulisan tersebut menggunakan metode deskriptif yang menerangkan bahwa rata-rata skor yang dicapai kelompok kontrol adalah 8,6 sedangkan rata-rata skor yang dicapai kelompok eksperimen adalah 14,39. Hal ini menunjukkan bahwa rata-rata skor hasil belajar IPA siswa pada kelompok eksperimen lebih besar dari pada rata-rata skor hasil belajar IPA siswa pada kelompok kontrol. Sementara itu dari hasil uji hipotesis dengan uji $\mathrm{t}$ diperoleh $t$-hitung $=5,194$ dan $t$-tabel $=2,021$ untuk $d b=49$ dengan taraf signifikansi 5\%. Ini berarti $\mathrm{H}_{0}$ ditolak dan $\mathrm{H}_{1}$ diterima. Dengan kata lain, adanya perbedaan hasil belajar IPA antara kelompok siswa yang belajar menggunakan metode Picture and Picture dengan kelompok siswa yang belajar menggunakan metode pembelajaran konvensional. Selain itu ditunjukkan bahwa hasil belajar IPA siswa dengan penerapan metode Picture and Picture lebih baik dari pada hasil belajar IPA siswa dengan pembelajaran konvensional. Hal tersebut disebabkan oleh kelebihan-kelebihan yang dimiliki oleh metode Picture and Picture yaitu (1) Guru lebih mengetahui kemampuan masing-masing siswa. (2) Guru dapat melatih siswa untuk berpikir logis dan sistematis.

Selain kelebihan yang dimiliki oleh metode Picture and Picture ada faktor lain yang turut serta membantu meningkatkan prestasi belajar IPA siswa ialah motivasi dan suasana belajar. Artinya selain motivasi yang mempengaruhi kemajuan pembelajaran siswa SD juga dapat dipengaruhi oleh suasana yang kondusif sehingga siswa lebih kosentrasi pada pembelajaran dan keributan dalam kelas dapat berkurang.

Dalam artikel lain yang ditulis oleh Nuraini Saleh (2012) dengan judul "Penerapan Pembelajaran Picture And Picture Untuk Meningkatkan Hasil Belajar IPA Kelas IV SDN 27" dengan memfokuskan pada materi struktur akar tumbuhan dan fungsinya dengan menggunakan model pembelajaran kooperatif tipe picture and picturemenjelaskan bahwa adanya perubahan nilai rata-rata hasil belajar siswa yang diperoleh pada masingmasing siklus yaitu pada pengamatan awal sebesar 64,09, lalu pada siklus 1 nilai rata-rata siswa menjadi 70,76 dan pada siklus 2 nilai rata-rata sebesar 75,15. Ini menunjukan bahwa hasil belajar IPA siswa, ketika diterapkan model pembelajaran kooperatif type picture and picture dalam pembelajarn IPA lebih tinggi bila dibandingkan dengan hasil belajar IPA siswa ketika belum diterapkan model pembelajaran kooperatif type picture and picture. Dengan demikian, penerapan model pembelajaran kooperatif type picture and picture dalam pembelajaran IPA pada materi struktur akar dan fungsinya, struktur batang dan fungsinya dapat meningkatkan hasil belajar siswa kelas IV Sekolah Dasar Negeri 27 Pontianak Tenggara. Wigatiningsih (2012) juga membahas pengaruh metode Picture And Picture dalam artikelnya yang berjudul "Penerapan Metode Picture And Picture Untuk Meningkatkan Minat Belajar Mata Pelajaran IPA Pada Siswa Kelas IV SDN 03 Sidomulyo Ampel Boyolali Tahun Pelajaran 2012/2013". Menunjukkan bahwa minat siswa dalam pembelajaran meningkat, yakni dari 45,48 (kategori kurang) pada pra siklus; menjadi 67,99 (berkategori baik) pada siklus I, dan 81,18 (berkategori baik) pada siklus II. Hal ini menunjukkan bahwa usaha guru dalam kegiatan pembelajaran IPA pada materi rangka tubuh manusia dengan menerapkan metode Picture and Picture sebanyak dua siklus pembelajaran dapat meningkatkan minat belajar siswa. 
Lebih lanjut Fifin Eka Yuliana (2016) dalam penelitiannya yang berjudul "Keefektifan Model Picture And Picture Terhadap Hasil Belajar IPA materi Perubahan Lingkungan Fisik Siswa Kelas IV Gugus Plangkawati Semarang". Menunjukan bahwa model pembelajaran picture and picture dapat meningkatkan hasil belajar IPApada materi perubahan lingkungan fisik siswa kelas IV. Hal ini dapat dilihat dari hasil analisis uji t nilai post test pada kelas eksperimen dan kelas kontrol didapat 9,38318 $>2,02$ sehingga $t_{\text {hitung }}>t_{\text {tabel. }}$ Berdasarkan analisis tersebut maka $\mathrm{H}_{0}$ diterima dan Ha ditolak. Hal ini dapat diartikan adanya keefektifan model pembelajaran picture and picture terhadap hasil belajar IPA materi perubahan lingkungan fisik siswa kelas IV SDN Gugus Plangkawati Semarang.

Penelitian lain yang dilakukan oleh Rizka Verdiana (2016) dengan judul "Pengaruh Model Pembelajaran Picture And Picture Dengan Media Dua Dimensi dalam Kegiatan Mengurutkan Daur Hidup Hewan Terhadap Kemampuan Mengurutkan Daur Hidup Makhluk Hidup Siswa Kelas IV SDN Puncu 1". Berdasarkan hasil penelitian tersebut diperoleh data thitung $>$ ttabel. yaitu 10,933 > 2,064 sehingga H0 ditolak dan Haditerima pada taraf signifikan (5\%). Dengan demikian dapat diartikan ada pengaruh signifikan dalam penggunaan model pembelajaran picture and picture dengan media dua dimensi dalam kegiatan mengurutkan daur hidup hewan terhadap kemampuan mengurutkan daur hidup makhluk hidup siswa kelas IV SDN Puncu 1.

\section{B. Pembahasan}

Melihat kelima artikel yang telah diuraikan sebelumnyadapat disimpulkan, hasil penelitian ini memberikan implikasi bahwa metode Picture and Picture dapat diterapkan dalam pembelajaran IPA sebagai upaya untuk meningkatkan hasil belajar siswa menjadi lebih baik, karena metode itu sendiri begitu berpengaruh dalam memberikan hasil belajar yang lebih baik. Ni Md. Kurniati, Dw. Nym. Sudana dan Ni Nym. Garminah (2012) mengungkapkan hasil belajar IPA dengan menggunakan metode picture and picture lebih baik dibandingkan dengan hasil balajar dengan metode pembelajaran konvensional. Hal tersebut selaras dengan yang diungkapkan oleh Nuraini Saleh yang menunjukkan bahwa ada peningkatan nilai rata-rata siswa persiklusnya dengan menggunakan metode picture and picture. Dan Wigatiningsih (2012) sependapat dimana meningkatnya minat siswa dalam pembelajaran, ditandai dari peningkatan persiklus juga yakni 45,48 (kategori kurang) pada pra siklus; menjadi 67,99 (berkatVegori baik) pada siklus I; dan 81,18 (berkategori baik) pada siklus II. Artinya, metode picture and picture sangat membantu siswa Sekolah Dasar dalam memahami pelajaran IPA karena ciri dari metode picture and picture adalah aktif, inovatif, kreatif dan menyenangkan (Istarani, 2011:7). Hal ini sesuai karena IPA pada muatan kurikulum 2013 adalah mata pelajaran yang memiliki peranan penting dalam mengembangkan keseluruhan aspek dari tingkat kemampuan siswa pada proses pembelajaran, hal ini dikarenakan IPA merupakan bagian dari mata pelajaran yang dikembangkan berdasarkan pencapaian pada tiga aspek yaitu pengetahuan, sikap dan keterampilan, sehingga dengan adanya proses pengembangan kepada ketiga aspek tersebut IPA memiliki peranan yang sangat penting terutama dalam mengembangkan kemampuan, sikap dan keterampilan ilmiah siswa. Kajian tersebut sesuai dengan Permendikbud Nomor 57 Tahun 2014 Pasal 5 Ayat 2 (2014: 3) mengenai konsep dasar dari mata pelajaran IPA yaitu:

Mata pelajaran umum kelompok A sebagaimana dimaksid pada ayat (1) huruf a merupakan program kurikuler yang bertujuan untuk mengembangkan kompetensi sikap, kompetensi pengetahuan, dan kompetensi keterampilan peserta didik sebagai dasar dan penguatan kemampuan dalam kehidupan bermasyarakat, berbangsa dan bernegara.

Jadi, untuk mempermudah pemahaman siswa guru perlu menggunakan metode pembelajaran yang tepat, sehingga siswa SD cepat menangkap dan memahami pelajaran yang disampaikan. Begitupun dengan pelajaran IPA perlu menggunakan media gambar atau metode picture and picture agar siswa cepat memahami materi yang dipelajari. Menurut Suprijono (2012:125) ada beberapa faktor sehingga siswa SD cepat memahami pelajaran IPA dengan menggunakan metode picture and picture, antara lain; Pertama, Siswa lebih cepat menangkap materi ajar karena guru menunjuk gambar. Kedua, gurumeminta siswa untuk menganalisis gambar yang ada. Ketiga, pembelajaran lebih berkesan karena siswa terlibat secara langsung.

Metode pembelajaran picture and picture memang menarik bagi siswa, dikarenakan melalui media gambar siswa akan lebih mudah memahami materi yang disampaikan oleh guru dan pelajaran lebih terlihat nyata serta siswa berperan aktif dalam proses pembelajaran. Walaupun seperti itu, tidak dipungkiri ada faktor lain yang menunjang sehingga metode picture and picture dapat efektif untuk pengembangan prestasi belajar siswa. Antara lain, membuat suasana interaktif, menantang siswa untuk dengancepat menguasai materi pembelajaran, memotivasi siswa untuk berpartisipasi aktif dalam memberikan masukan berdiskusi dan menjawab soal yakni suasana kelas yang kondunsif dan cara guru untuk memotivasi siswa dalam pembelajaran. Penggunaan metode picture and picture tidaklah berjalan dengan mulus, karena ada beberapa kelemahan dalam penerapannya. Adapun kekurangan model pembelajaran picture and picturemenurut Istarani (2011: 9) diantaranya: Sulit menemukan gambar yang bagus dan berkualitas sesuai kompetensi dari 
materi yang akan diajarkan. Memerlukan waktu yang lama dalam pembelajarannya.jika guru kurang ahli dalam mengelola kelas, ada kekhawatiran kelas akan kacau dan tidak kondusif. Dibutuhkan dukungan fasilitas, alat, biaya yang cukup memadai.

Menurut penulis, Kekurangan yang ada dalam model pembelajaran picture and picture, dapat diatasi dengan beberapa usaha. Misalnya mengenai sulitnya mencari gambar yang cocok dengan kompetensi. Dalam hal ini, guru dapat membuat gambar sendiri sehingga guru dapat menyesuaikan dengan materi. Kemudian usaha lain yang dapat dilakuakan oleh guru yakni melalui situs internet. Guru bisa mengunduh dari situs penyedia gambar sesuai materi pembelajaran IPA. Dewasa ini perkembangan teknologi informasi begitu pesat. Jadi, untuk menemukan sesuatu yang kita cari sangat mudah.Namun, dalam menggunakan media internet ada kendala tertentu yang tidak memungkinkan bisa digunakan dengan mudah. Hal itu karena masih adanya desa-desa di pelosok atau desa yang jauh dari pusat kota yang belum terjangkau oleh teknologi informasi merupakan salah satu kendala dalam menggunakan internet untuk mencari dan menemukan gambar yang sesuai dengan materi. Namun, internet tetap menjadi salah satu media yang cepat untuk menemukan gambar yang diinginkan.

Terkait permasalahan waktu yang relatif lama, sebelum pembelajaran guru harus sudah mengalokasikan waktu dengan tepat dan segala sesuatu yang dibutuhkandalam proses pembelajaran seperti media gambar sudah dipersiapkan terlebih dahulu, sehingga proses pembelajaran dapat berjalan lancar.

\section{SIMPULAN DAN SARAN}

\section{A. Simpulan}

Berdasarkan hasil kajian, maka dapat disimpulkan bahwa ada pengaruh dari penggunaan model pembelajaran picture and picture terhadap prestasi belajar siswayang dapat dilihat dari perbedaan hasil belajar siswa yang menggunakan model pembelajaran picture and picture dengan model pembelajaran konvensional seperti ceramah tanpa ada media pembelajaran lain. Dimana dengan menggunakan model pembelajaran picture and picture prestasi belajar siswa meningkat dan lebih optimal. Meskipun dijumpai beberapa kelemahan dalam penggunaan model pembelajaranpicture and picture. SepertiSulit menemukan gambar yang bagus dan berkualitas, tetapi hal tersebut dapat diatasi dengan pemanfaatan media internet.

\section{B. Saran}

Model pembelajaran yang berbasis pada picture and picture adalah salah satu model pembelajaran yang dianggap sulit oleh beberapa pendidik, baik pada tingkatan sekolah dasar, pertama, menengah atas, maupun pendidikan tinggi, hal ini tentu disebabkan oleh kedudukan pendidik yang harus memahami dua konsep diantaranya konsep materi yang diajarkan dan konsep picture and picture yang menggambarkan materi yang diajarkan, selain itu upaya meningkatkan atau melatih kreatifitas peserta didik membutuhkan keterampilan khusus bagi para pendidik karena kreatifitas merupakan jenis keterampilan berpikir tingkat tinggi, untuk itu disarankan kepada pendidik agar mampu memahami rencana pembelajaran berbasis analogi secara mendalam serta mempelajari instrument tes berpikir kreatif agar mampu melatih kemampuan berpikir kreatif peserta didik secara maksimal.

\section{DAFTAR RUJUKAN}

Awing. S. I. 2015.Kesulitan Belajar IPA PesertaDidikSekolahDasar. Jurnalvoxedukasi.Vol 6. No 2. STKIP PersadaKhatulistiwa.

Depdiknas. 2006. Peraturan Menteri Pendidikan Nasional RI No 22 Tahun 2006 Tentang Standar Isi untuk Satuan Pendidikan Dasar dan Menengah. Jakarta: Depdiknas.

Fitrih. 2016. Efektifitas Model Pembelajaran Arias (Assurence, Relevance, Interest, Assesment, SDN Sungguminasa Ii Kabupaten Gowa. Skirpsi tidak diterbitkan. Makassar: Universitas Muhammadiyah Makassar

Gamiarsy. M. W. 2017. Pengaruh Penerapan Model Pembelajaran Kooperatif Tipe Picture And Picture Terhadap Hasil Belajar IPA Siswa Kelas V SDN 1 Sri Pendowo Ketapang Lampung Selatan. Skripsi. Fakultas Keguruan dan Ilmu Pendidikan Universitas Lampung.

Hidayat. 2014. Penerapan model pembelajaran picture and picture untuk meningkatkan hasil belajar IPA siswa kelas IV MIN Ngawen Gunungkidul Yogyakarta. Skripsi. Fakultas Tarbiayah dan Ilmu Keguruan Universitas Islam Negeri Sunan Kalijaga Yogyakarta.

Istarani (2011). 58 Model Pembelajaran Inovatif. Medan: Media Persada 
Ni Md. Kurniati, Dw. Nym. Sudana dan Ni Nym. Garminah. 2012. Pengaruh Metode Picture And Picture Terhadap Hasil Belajar Ipa Siswa Kelas IV SD Semester Genap Di Gugus I Kecamatan Buleleng. Pendidikan Guru Sekolah Dasar, FIP Universitas Pendidikan Ganesha Singaraja, Indonesia

Nuraini Saleh. 2012. Penerapan Pembelajaran Picture And Picture Untuk Meningkatkan Hasil Belajar Ipa Kelas IV SDN 27. Program Pendidikan Guru Dalam Jabatan Fakultas Keguruan Dan Ilmu Pendidikan Universitas Tanjungpura Pontianak

Permendikbud RI Nomor 57 Tahun 2014 Tentang kurikulum 2013 sekolah dasar/Madrasah Ibtidaiyah.

Purwoko, Budi. Mirzaqon, A. 2017. Study Kepustakaan Mengenai Landasan Teori dan Praktik Konseling Expressive Writing. Jurnal .Fakultas Ilmu Pendidikan , Universitas Negeri Surabaya.

Subratayasa, I Made. 2012. Implementasi Metode Picture and Picture dalam rangka meningkatkan hasil belajar Sains siswa kelas IV semester genap di SD I Marga, Kecamatan Marga, Kabupaten Tabanan Tahun Pelajaran 2011/2012. Skripsi (tidak diterbitkan). Jurusan Pendidikan Guru Sekolah Dasar Fakultas Ilmu Pendidikan, Universitas Pendidikan Ganesha Singaraja.

Suprijono, Agus. 2012. Cooperative learning. Yogyakarta: Pustaka Pelajar

Supriyadi. 2016. Solusi alternatif berbagi pengetahuan antara pustakawan. Jurnal lentera pustaka.

Susmartini, Adi. 2011. Peningkatan Kemampuan Mendeskripsikan Daur Hidup Hewan dengan Strategi Picture And Picture pada Siswa Kelas IV SDN 01 Celep Kedawung Sragen Semester 1 Tahun Pelajaran 2010/2011. Skripsi thesis. Universitas Muhammadiyah Surakarta.

Tim Penyusun PKKI. 2015. Pedoman Penulisan Karya Ilmiah. Bima: Sekolah tinggi keguruan dan ilmu pendidikan (STKIP) Taman siswa Bima.

Undang-Undang No 20 tahun 2003 tentang Sistim Pendidikan Nasional

Verdian, Rizka. 2016. Pengaruh Model Pembelajaran Picture And Picture Dengan Media Dua Dimensi dalam Kegiatan Mengurutkan Daur Hidup Hewan Terhadap Kemampuan Mengurutkan Daur Hidup Makhluk Hidup Siswa Kelas IV SDN Puncu 1. Skripsi. Universitas Nusantara PGRI kediri.

Wigatiningsih .2012. Penerapan Metode Picture And Picture Untuk Meningkatkan Minat Belajar Mata Pelajaran Ipa Pada Siswa Kelas Iv Sdn 03 Sidomulyo Ampel Boyolali Tahun Pelajaran 2012/2013. Ilmu Pendidikan UniversitascMuhammadiyah Surakarta.

Yuliana, Eka. 2016. Keefektifan Model Picture And Picture Terhadap Hasil Belajar IPA Materi Perubahan Lingkungan Fisik Siswa Kelas IV Gugus Plangkawati Semarang. Skripsi. Universitas Negeri Semarang. 